\title{
BOTANIC GARDENS, EDUCATION, AND ORCHID CONSERVATION STRATEGIES: THE NEED FOR A COORDINATED APPROACH
}

\author{
Thomas J. MiRenda
Smithsonian Institution, P. O. Box 37012, Greenhouse Nursery Operations, Washington, D.C. 20013-7012, U.S.A. \\ MirendaT@si.edu
}

\begin{abstract}
Aвstract. The call for orchid conservation has been heard worldwide by scientists, horticulture professionals, commercial propagators, and passionate private enthusiasts, all with different opinions and approaches on how to tackle this worldwide problem. The news has been dire with the prospects of global warming, habitat destruction, displacement of natives by aggressive exotics, unsustainable plant predation/harvesting, and impotent efforts to enforce legal protections. Considerable thought and effort have gone into specific strategies for orchid conservation, including habitat protection, buying and preserving 'hot spots', and the trends toward creating horticultural reserves, both native (Lankester Gardens, Ecominga Foundation, Ecuagenera reserves) and ex situ (orchid gardens in Hawaii, collections under glass, etc.) Tactics such as seed-banking, DNA technology, ex situ propagation efforts, and eventual reintroductions are inherently dependent on the resources and holdings of botanic gardens and responsible commercial growers. It is such horticultural work that has saved genera such as Franklinia, Torreya, and Wollemia as well as orchid species such as Paphiopedilum vietnamense, Epidendrum ilense, and Angraecum longicalcar from complete extinction. Botanic gardens, while united by certain organizations such as the American Public Garden Association (APGA) and Botanic Garden Conservation International (BGCI), need greater cooperation and coordination of their plant conservation efforts. In addition, it is critical for botanic gardens to engage the scientific community (and vice versa), especially those who can best assess which species are the most endangered. If collections are to be used optimally, the scientific and horticultural communities must become more aware of each other's assets and priorities. At the first International Orchid Conservation Congress (IOCC), four resolutions were adopted from the Global Strategy for Plant Conservation (GSPC): 1) 90\% of all threatened orchids should be secure in ex situ collections; 2) 50\% should be in active recovery programs; 3 ) no orchids should be threatened by unsustainable harvesting; and 4) every child should be aware of plant diversity (including orchids) by 2010. How do we assess whether progress has been made toward these admirable goals without a unifying entity to compile the progress, information, and successes? With so much effort going on in so many separate places, such an entity is sorely needed. In addition, the plant conservation community needs more coordination with the efforts of the animal conservation community. It is the goal of many botanic gardens and a specific goal of the Smithsonian Institution to promote the diffusion of knowledge and understanding. To this end, goal \# 4 above is a particular priority. While reaching the goal of $100 \%$ awareness of plant diversity by 2010 is not possible, we have undertaken various educational initiatives aimed at promoting conservation awareness in our visitors, especially young people. For educators, it is imperative to instill these values at an early age.
\end{abstract}

RESUMEN. Se ha escuchado a nivel mundial el llamado para la conservación de orquídeas, por parte de científicos, profesionales de horticultura, propagadores comerciales y los apasionados entusiastas privados, todos con diferentes opiniones sobre la manera para atacar este problema global. Las noticias han sido desalentadoras en relación al calentamiento global, destrucción de hábitat, desplazamiento de poblaciones nativas por parte de agresivas, exóticas e insostenibles depredaciones /cosechas de plantas y los esfuerzos impotentes para hacer cumplir las protecciones legales. Se han dedicado muchas ideas y esfuerzos para determinar estrategias específicas para la conservación de orquídeas, incluyendo la protección al hábitat, la compra y preservación de los "puntos calientes," así como las tendencias hacia la creación de reservas hortícolas, tanto nativas (reservas de los Jardines de Lankester, Fundación EcoMinga, Ecuagenera) y ex situ (jardines de orquídeas en Hawái, 
colecciones bajo vidrio, etc.). Tácticas como un banco de semillas, tecnología ADN, esfuerzos de propagación ex situ, así como eventuales reintroducciones, inherentemente dependen de recursos y propiedades de jardines botánicos y cultivadores comerciales responsables. Es este tipo de trabajo de horticultura el que ha salvado a otros géneros que no corresponden a las orquídeas, tales como Franklinia, Torreya, Wollemia, y especies de orquídeas como Paphiopedilum vietnamense, Epidendrum ilense, y Angraecum longicalcar de la extinción. Los jardines botánicos unidos bajo ciertas organizaciones como la Asociación Americana de Jardines Públicos (American Public Garden Association - APGA) y Jardines Botánicos para la Conservación Internacional (Botanic Garden Conservation International - BGCI), necesitan de una mayor cooperación y coordinación para el éxito de sus esfuerzos para la conservación de plantas. Además, es un aspecto crítico que los jardines botánicos se conecten con la comunidad científica (y viceversa), especialmente aquellos que mejor pueden asesorar sobreaquellas especies más amenazadas. Si las colecciones van a ser utilizadas en forma óptima, las sociedades científicas y de horticultura deben estar más conscientes de sus respectivos activos y prioridades. En el Primer Congreso Internacional para la Conservación de Orquídeas (International Orchid Conservation Congress - IOCC), se adoptaron cuatro resoluciones de la Estrategia Global para la Conservación de Plantas (Global Strategy for Plant Conservation - GSPC en inglés): 1): el 90\% de todas las orquídeas amenazadas deberían ser asegurada en colecciones ex situ; 2) el 50\% debería constar en programas para su recuperación activa; 3 ) Se debe considerar que las orquídeas están amenazadas cuando su cosecha no es sostenible; y 4) Para el año 2010, cada niño y niña debe estar consciente de lo que es la diversidad de plantas (incluyendo a las orquídeas). ¿C.mo podemos evaluar si se está logrando el progreso hacia estos admirables objetivos sin que exista una entidad que unifique y que pueda recopilar el progreso, la información y el grado de éxitos alcanzado? Al ver el esfuerzo desplegado en tantos lugares separados, es indudable que se necesita urgentemente este tipo de entidad. Constituye la meta de muchos jardines botánicos y una meta específica del Instituto Smithsoniano, el promover la diseminación de conocimientos y comprensión. Con este fin en mente, el anterior objetivo \#4 constituye una particular prioridad. A pesar de que alcanzar la meta del $100 \%$ de conciencia compartida en relación a la diversidad de plantas para el año 2010, hemos iniciado un proyecto que nos permita comprender y finalmente corregir el llamado síndrome de "Ceguera relativa a las Plantas," bajo el cual la persona promedio no considera que las plantas son seres vivientes (en el mismo sentido de los animales). Mediante el uso de encuestas y entrevistas personales, se está analizando este síndrome generalizado y penetrante para determinar sus caracter.sticas demográficas, hombre/ mujer, urbano/rural, jóvenes/ viejos, etc. Es imperativo para los educadores que identifiquen la edad en la cual dichas actitudes empiezan a introducirse en la psiquis de los jóvenes. Es necesario aplicar ciertas técnicas que permitan elevar el grado de conciencia de los individuos de todas las edades en relación a la importancia de la diversidad de las plantas y su conservación. Esto puede tomar la forma de presentaciones, exposición a especies representativas, paseos de campo y otras oportunidades educativas, que permitan cultivar un enfoque mental que comprenda y a la final proteja el mundo natural.

KEY WORDS: orchids, conservation, ex situ collections, recovery, education

Worldwide efforts of the wildlife conservation movement have increased dramatically in the last decade. Ambitious projects such as the 'barcoding of life' initiative have brought a wide variety of scientists from disparate disciplines together to work on strategies and solutions to tackle some of the world's most vexing problems (C. Valladares-Padua, unpublished). With the fire of global warming lit beneath us, it is increasingly clear that the present generation of scientists, conservationists, and legislators have the obligation to engage in innovative thinking to preserve species and habitat diversity as well as to do everything in their power to change course before mass extinction occurs (W. F. Laurance, unpublished). In the animal conservation community, many protocols have been adapted that could help the botanical community achieve its conservation goals. The purpose here is to create awareness of some of the successes and failures of the zoological community in the hope that we can learn from and adapt these practices to improve our own efforts to protect imperiled plants.

The orchid community, by nature of the passion 
evoked by this charismatic plant family, has been a leader in plant conservation efforts. With a colorful history of rampant wild collection, habitat destruction, pollinator specificity, and displaying unparalleled species and population diversity, an awareness of the need for conservation policy has been long understood among orchidophiles. Organizations such as the IUCN Orchid Specialist Group, Orchid Conservation International (http://www.orchidconservation.org/ $\mathrm{OSG} /$ ), the Orchid Conservation Alliance, and the Ecominga Foundation (http://ecominga.net/) have supported numerous projects around the world aimed at preserving orchid habitats, particularly IPAs (Important Plant Areas), that are natural hotspots for orchid species diversity. Many other organizations and individuals are working in virtual isolation toward the same goals. As admirable as these efforts are, more coordination, collaboration, and focus are necessary to achieve desired long-term goals.

In addition to preserving IPAs, orchid conservation efforts are necessarily dependent on the success of reforestation and habitat reconstruction projects. If the ultimate goal of our conservation efforts is to return extirpated orchids to their original wild habitats, then such efforts are futile when those habitats no longer exist. Without a suitable ecosystem to support it, including the entire milieu of plants, insects, and other pollinators, orchid plants may survive for a time, but they will not thrive and be able to reproduce. The work of Chazdon (2009) showed that rebuilding an ecosystem may not be as difficult as previously thought. Her work focused on secondary forests in Costa Rica. Though not as ideal for habitat as primary forest, such forests can still contain up to $80 \%$ of the tree species found in primary forest. If left alone or supplemented with absent species, these forests could still be excellent habitats for reintroduction of orchids. At the very least, such forests can serve as a buffer between primary forests and agricultural monocultures.

Botanical gardens have a crucial role to play in orchid conservation strategy. The usual role of botanic garden collections is for horticultural display, visitor enjoyment, and education. This contribution should not be underestimated as it is likely the only opportunity for the majority of people to witness the diversity of plants outside their own heavily altered environment. Many present-day leaders in the botanical community got their first glimpse of the plants in which they now specialize while visiting a botanic garden. The development of kidfriendly exhibits such as the USBG's Alphabet Garden of Orchids as well as the Smithsonian Institution's development of orchid-related texts in grade-school and highschool textbooks should pay off in greater public consciousness and the development of the next generation of conservation biologists.

Such garden collections, if properly documented and kept disease-free, are also repositories for endangered species and as such can serve as a source for genetic material for ex situ breeding programs. Often considerably less well funded than zoos, with a few exceptions, most botanical gardens have not yet realized their conservation potential in the same way as their animal counterparts. Organizations such as Botanic Gardens Conservation International (http:// www.bgci.org) and the American Public Garden Association (APGA; http://www.publicgardens.org/) seek to advance plant conservation efforts by following and promoting the advancement of the Global Strategy for Plant Conservation (http://www.cbd.int/gspc/). While they've been successful in achieving these goals in developed countries, most of the orchid diversity occurs in less-developed nations where the economic climate precludes prioritizing plant conservation. Small details such as the need for translations into English are often keeping thousands of species from being redlisted, the first important step to their protection.

More specifically, at the first International Orchid Conservation Congress (IOCC), four resolutions were adopted from the Global Strategy for Plant Conservation (GSPC):

1. $90 \%$ of all threatened orchid species should be secure in ex situ collections. While progress has definitely been made toward achieving this admirable goal, it seems certain that with so many endemic species in countries such as Ecuador that have yet to be even red-listed, we haven't as yet placed close to $90 \%$ of threatened orchid species in ex situ situations. It is incumbent on institutions in the developed world to help get these species listed and sent to appropriate botanic gardens to ensure their survival.

2. $50 \%$ of threatened orchids should be in active recovery programs. Since this goal depends on 
resolution \#1 having been achieved, we find ourselves unable to progress well with this important task. Plant reintroductions and recovery programs are considerably more complicated and fraught with difficulty than we thought 10 years ago. The need to restore forest (and other) habitats as well as the species diversity within them requires the participation of a large number of biologists to understand fully the implications of such projects on the ecology of any given region. However, a few such projects have been successful, including efforts by Henry Doorly Zoo (http://www.omahazoo.com/index.php?p =c onservation\&s=rareplantresearch) and the Royal Botanic Gardens, Kew, to recover and reintroduce orchids in Madagascar, the Ecominga foundation in Ecuador, and similar initiatives in Costa Rica and Panama.

3. No orchids should be threatened by unsustainable harvesting. While much of the illegal harvesting of wild orchids has been curtailed by the enforcement of laws resulting from the Convention on the International Trade in Endangered Species (CITES), some illicit and unsustainable activity persists in the orchid world. The most recent evidence of this is the voracious pillaging of the habitats of Paphiopedilum vietnamense (O.Gruss \& Perner) and Phragmipedium kovachii J.T.Atwood, Dalstr.m \& Ric.Fern.ndez. These horticulturally important plants were plundered mercilessly by commercial orchid companies and private individuals. Efforts to control their trade were undermined in several ways. In the case of $P$. vietnamense, the local authorities were unable to control or enforce laws against wild collection, resulting in their virtual extirpation in the wild. In addition, smuggled plants acquired by CITES rescue centers were propagated in the hope that inexpensive, artificially produced propagules would reduce wild-collection pressure. Although this effort was successful, it also created a smokescreen for many illegally collected plants to enter the trade. Conservation efforts for Phragmipedium kovachii have been more successful due the active participation of the Peruvian government in the protection and propagation effort for this valuable species. The lesson learned here is that the engagement of local stakeholders will usually result in better stewardship of endangered species both in the wild and in cultivation.

4. Every child should be aware of plant diversity (including orchids) by 2010. Although reaching every child in the world is a daunting goal, admirable progress has been made on this resolution. With the worldwide consciousness raised in the need for conservation of species, remediation of global warming, and the value of our natural systems, it seems likely that the next generation of students will be keenly aware of the importance of biological (including botanical) diversity for the continued health of our planet.

In contrast to their zoological counterpart, the Association of Zoos and Aquariums (AZA), botanical organizations do not require their member gardens to engage in conservation efforts with their collections, although initiatives of APGA such as the NAPCC (North American Plant Collections Consortium) promise a future database where germplasm from a network of collections can eventually be accessed and used for breeding purposes. Accreditation by the AZA is contingent on the participation of all zoos possessing endangered species in their collection in captive breeding programs. Zoo staff from all participating institutions are required to follow specific protocol and have input in international SSPs (Species Survival Plans), TAGs (Taxon Advisory Groups), and SAGs (Scientific Advisory Groups) for their endangered holdings. These are associated with databases that record husbandry and collection data to prevent inbreeding and encourage genetic diversity within captive populations. The plant community could benefit greatly from adopting similar tactics for the plant resources in botanic gardens and other orchid species collections.

Much work has been done in the U.K. and U.S. with the cryopreservation and banking of orchid seed. Projects such as the OSSSU (Orchid Seed Stores for Sustaniable Use) and the Orchid Seedbank Project may indeed be the best hope for preserving plant populations. Individual plants in botanic gardens have their worth but represent only one set of genes. Space requirements would certainly limit the quantity 
of any given taxon in a botanic garden. Seedbanking also preserves some genetic diversity and should be encouraged and supported for eventual reintroduction projects.

Other lessons to be learned from the animal world include an analysis of their prowess at outreach, fund-raising, and public engagement. The Internet represents a vast, untapped opportunity to harness a tremendous interest in orchids that clearly exists when all the myriad websites devoted to orchid species culture and discussion are considered. The website for the organization Amphibian Ark (http://www. amphibianark.org) is a prime example of how to use the Internet as a fund-raising tool, building the awareness of the need for public engagement and reaching out to many constituencies, especially children. Another virtually untapped source of outreach is the media. More articles need to be written in popular magazines rather than scientific journals if conservation goals are to be understood and promulgated among more people. And, finally, wild animals have been featured on television for generations and have notable personalities and celebrities advocating their conservation, yet the plant world has only 'gardening-type' programming. With the astounding array of ecological niches, deceptive pollination strategies, and charismatic young people deeply involved in orchid conservation biology, we should be producing and promoting programming that will engage the public, raise their consciousness, and directly involve them in orchid conservation efforts.

Perhaps most importantly, it has become apparent within the animal conservation community that a more holistic approach to conservation is necessary for success. The case history of the Takhi (the Mongolian wild horse) is a prime example of a reintroduction project that focused specifically on the animal without fully taking into consideration its foraging needs (http://nationalzoo.si.edu/ConservationAndScience/ $\mathrm{CRC} /$ ). With just enough vegetation to support the dominant male and his females, the rest of the reintroduced herd starved. The inclusion of botanical expertise to restore the habitat of the Takhi prior to reintroduction would have produced better results. It will always be necessary for animal and plant biologists to collaborate on conservation projects in the same way that plants and animals, on the most basic level, need each other to survive. It's imperative that botanists and zoologists develop plans (and apply for grants) together that address the interconnected needs of flora and fauna.

\section{LiTERATURE CITED}

Chazdon, R. L., Peres, C. A., Dent, D., Sheil, D., Lugo, A. E., Lamb, D., Stork, N. E., and Miller, S. E. 2009. The potential for species conservation in tropical secondary forests. Conserv. Biol. 23: 1406-1417.

Electronic sources:

http://www.amphibianark.org/np accessed 10/2008 http://www.bgci.org/np accessed 10/2008

http://nationalzoo.si.edu/ConservationAndScience/CRC/ np accessed 10/2008

http://www.orchidconservation.org/OSG/ np accessed 10/2008

http://www.orchidconservationalliance.org/ np accessed 10/2008

http://www.publicgardens.org/np accessed 10/2008

http://www.cbd.int/gspc/ np accessed 10/2008 http://ecominga.net/ np accessed 10/2008

http://www.omahazoo.com/index.php? $p=$ conservation\&s=rareplantresearch $n p$ accessed 10/2008 